\title{
Butterfly assemblages in plantation forest and degraded land, and their importance to Clean Development Mechanism-Afforestation and Reforestation
}

\author{
Kiyoshi NaKamuta $^{1}$, Kazuma Matsumoto ${ }^{2, *}$ and Woro A. NoERdito ${ }^{3}$ \\ Research Planning and Coordination Department, Forestry and Forest Products Research Institute, Matsunosato 1, Tsukuba, 305-8687, \\ Japan \\ Department of Forest Entomology, Forestry and Forest Products Research Institute, Matsunosato 1, Tsukuba, 305-8687, Japan \\ Museum Zoologicum Bogoriense, PUSLITBANG Biologi, LIPI, Cibinong, Jawa Barat, Indonesia \\ *Corresponding author: Tel: +81-29-829-8254, Fax: +81-829-873-1543, E-mail: kazuma@ffpri.affrc.go.jp
}

\begin{abstract}
To know the effect of plantation on biodiversity in a degraded land, we compared butterfly fauna between a heavily degraded area dominated by grasses, Themeda triandra and Heteropogon contortus, and a nearby plantation forest both on Lombok, Indonesia. We found that forest plantation onto the degraded land did not damage the butterfly fauna in planted area. Extrapolating the present results we discuss impacts on biodiversity that we have to consider when we are engaged in an afforestation and reforestation Clean Development Mechanism project.
\end{abstract}

Key words: butterfly, biodiversity, CDM-A/R, environmental impact, Lombok, Indonesia

\section{INTRODUCTION}

The clean development mechanism (CDM) is defined as one of the innovative flexibility mechanisms (Kyoto Mechanisms) to lower the overall costs for achieving emission reductions of green house gases in COP 3 of the United Nations Framework Convention on Climate Change (UNFCCC) (United Nations, 1998). The industrialized countries may implement projects that reduce emissions in the developing countries, or absorb carbon through afforestation or reforestation activities, in return for certified emission reductions, and to assist the host parties in achieving sustainable development and contributing to the ultimate objective of the convention.

Project participants of afforestation and reforestation $\mathrm{CDM}(\mathrm{CDM}-\mathrm{A} / \mathrm{R})$ are requested to document and analyse the environmental impacts, including those on biodiversity and natural ecosystems, and those outside the project boundary of the proposed CDM-A/R project activity. If any negative impact is considered significant by the project participants or the host party, a statement should be made that project participants have undertaken an environmental impact assessment, in accordance with the procedures required by the host party, including conclusions and all references to support documentation (United Nations, 2005).

However, available information for forecasting effects of CDM-A/R project on biodiversity is very limited in the tropics, due to lack of biodiversity studies from non-forest areas such as Imperata grasslands resulting from forest degradation, and plantation forest areas, although biodiversity in the primary or old growth forests (Ashton, 1971; Erwin and Scott, 1980; Worda, 1978, 1983; Whitmore, 1990; Robinson and Tuck, 1993; Crambrook and Edwards, 1994: papers that appeared in Edwards et al., 1996; Primack and Corlett, 2005), and, more recently, disturbed (logged-over and/or burnt) forests (e.g., Hill et al. 1995; Spitzer et al. 1997; Willot et al. 2000; Lewis, 2001; Lehtonen et al. 2001; Slik et al, 2002; papers that appeared in Lammertink et al. 2004; Cleary and Mooers, 2006) has been attracting much more attention.

We, therefore, conducted a comparison of insect fauna between a heavily degraded area dominated by grasses, Themeda triandra and Heteropogon contortus, and a plantation forest to know the effect of plantation on biodiversity in a degraded land. We have carried out a series of surveys on the butterflies in the Japan-Indonesia Friendship Forest at Sekaroh, Lombok, Indonesia to estimate present status of these insects from a viewpoint of biodiversity improvement. Butterflies are useful for assessment of recovery of forest insect fauna, because they are well studied taxonomically and biogeographically and there are a good number of species exhibiting various habitat preferences, ranging from open habitat species to forest species, so that species composition of the butterflies can be an indicator of the recovery of forest fauna. 


\section{MATERIALS AND METHODS}

Study sites and methods

Field study was conducted in the reforestation area of Japan-Indonesia Friendship Forest, established in 1996 through the collaboration between the Indonesian Ministry of Forestry and Japan International Forestry Promotion and Cooperation Center, and an adjoining deforested grassland at Sekaroh, southeastern coast of Lombok, Indonesia.

An agro-forestry system was employed, and farmers around the plantation were allowed to plant rice and vegetables for several years after planting. Logging of trees was prohibited. The plantation suffered repeated fires after planting and burnt areas were replanted in 1999.

According to precipitation records from the nearest meteorological station at Keruak for 1998-2002, average annual precipitation $( \pm \mathrm{SD})$ is $1,132 \pm 290 \mathrm{~mm}$ and dry season (with less than $100 \mathrm{~mm}$ rainfall per month) lasts for six months, indicating that this region belongs to Ustic (seasonally dry) zone. The soil is mainly Regosol associated with eutric Fluvisol and humic Gleysol (FAOUNESCO, 1979). The primary vegetation has been mostly lost, and replaced with a tropical seasonal forest where thorny bush (Monk et al., 1997) and, on wetter slopes, Grewia acuminata predominates (Kiyono and Rachman, 2004, 2005).

Tree species planted in the area are Cassia siamea, Melia azedarach, Dalbergia latifolia, Tectona grandis, Ceiba pentandra, Swietenia macrophylla, Leucaena leucocephala, Tamarindus inidica, Anacardium occidentale, Annona squamosa and Artocarpus heterophyllus, all of which were introduced and have been cultivated for long periods on Lombok. Lantana camara was the dominant undergrowth in the reforested area. Five sites (F1 to F5) in the reforested area were chosen for sampling butterflies. These five sites underwent different reforestation regimes during 1996-1999, including re-reforestation after a fire, as indicated in Fig. 1.

Two sites (G1 and G2) in the grasslands were also chosen for sampling. Site G1 was mostly covered with grasses, $T$. triandra and $H$. contortus, and studded with an introduced shrub species, Zizyphus jujuba. The vegetation in Site G2 was similar, but small clumps of wild trees were also found in this site, and the grassland was bounded by a natural (maritime) forest growing along the sea coast (Fig. 1).
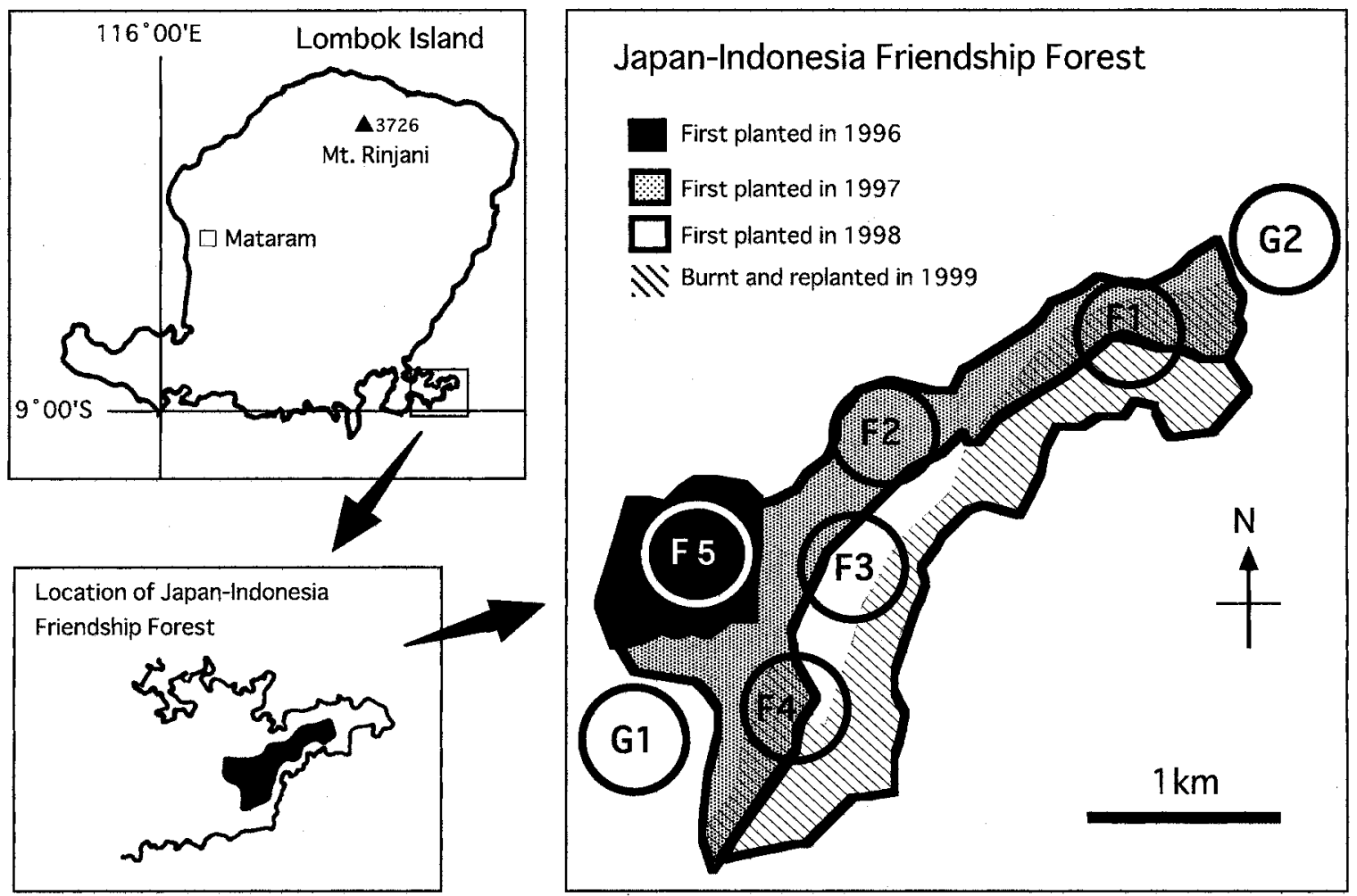

Fig. 1. A map of the Japan-Indonesia Friendship Forest in Sekaroh, Lombok, Indonesia. indicates area initially planted in 1996, burnt after initial planting and replanted in 1999. 
Preliminary sampling in the reforested area was done by random hand-netting, visiting each site twice or taking ca. 40 to 50 minutes in total per site during August 26-30, 2003 (dry season). For the following regular sampling, butterflies were collected by two persons for 45 minutes for each visit to a site. We visited each site in the reforested area twice during January 3-7, 2004 (wet season), once June 23-25, 2004 (beginning of dry season), three times January 5-10, 2005, once September 11-15, 2005 and twice during January 25-28, 2006. Sampling at Site G1 was also done in a similar way, from June, 2004 onward, but we did not conduct sampling in this site in January, 2004. Sampling at Site G2 was done only in June, 2004, September, 2005 and January, 2006.

\section{Characteristics of the species}

The characteristics of the butterfly species were analyzed by their main habitat types, geographic distribution patterns and larval food plants. Information on these points was obtained from Tsukada and Nishiyama (1980), Yata and Morishita (1981), Aoki et al. (1982), Fukuda et al. (1982, 1983, 1984a, b), Ackery and Vane-Wright (1984), Tsukada (1985, 1991), Maruyama and Otsuka (1991), Seki et al. (1991), Corbet and Pendlebury (1992), de Jong and Treadaway (1993), Otsuka (1996), Igarashi and Fukuda (1997, 2000), Bascombe et al. (1999), Braby (2000), Tennnent (2002), Vane-Wright and de Jong (2003), and de Jong (2004). The species were categorized into grassland species, savanna species, forest edge species, forest species and multi-habitat species based on habitat types mainly preferred by them. The geographical ranges were categorized with increasing scale as follows:
1. Lesser Sunda Islands
2. Sundaland and Wallacea
3. Asian tropics including Wallacea
4. Oceanian tropics including Wallacea
5. Asian and Oceanian tropics
6. Asian, Oceanian and African tropics

\section{Data analysis}

Species richness was estimated by Jackknife method (Jackknife 1 and 2; Smith and van Belle, 1984; Palmer, 1991) for the whole reforestation area based on 55 samples which consist of 11 samples for each of the five sites (the preliminary samples taken in August 2003 were included here). The Jackknife estimation was also applied to Sites F1-5 and G1 using eight samples from each site (June 2004 to January 2006) for comparison between sites.

Species richness in the reforestation area was also evaluated by comparing the number of species collected in the area with the number of species known from Lombok. Total numbers of species of the families Papilionidae, Pieridae and Nymphalidae occurring on Lombok are obtained from Tsukada and Nishiyama (1980), Yata and Morishita (1981), Aoki et al. (1982) and Tsukada $(1985,1991)$, as well as our new records. To our knowledge, the faunal documentation for Hesperiidae and Lycaenidae on Lombok is not available, so that we omitted these two families from the comparison.

Species diversity for each site was computed by taking inverse form of Simpson (1949) index as recommended by Morisita (1996) as follows:

$$
1 / D=\sum \frac{N(N-1)}{N_{i}\left(N_{i}-1\right)},
$$

where $D$ is the Simpson index, $N_{i}$ is the number of individuals for $i$ th species, and $N$ is the total number of individuals in the sample, irrespective of species.

\section{RESULTS}

\section{Butterfly assemblage in the study area}

Table 1 shows the list of butterflies collected at each study site in the Friendship Forest and the adjacent degraded area (grassland) together with their habitat preferences and geographical ranges. Total number of species collected was 70, including seven species of Hesperiidae, six Papilionidae, 15 Pieridae, 12 Lycaenidae and 30 Nymphalidae (12 Danainae, four Satyrinae, four Heliconiinae, two Limentidinae, one Charaxinae and seven Nymphalinae). We recognized 15 grassland species, seven savanna species, 17 forest edge species, 24 forest species and seven multi-habitat species. Butterflies of all the five habitat types were found at each sampling site. Many forest edge species were recorded in the reforested area and Site G2 (Fig. 2). Forest species were frequently encountered in the reforested area except Site F4, and very rare in Site G1. Most forest species were widely ranging species, and only Delias oraia was endemic to Lesser Sunda. Twenty-eight species (five hesperiids, five papilionids, two pierids, three lycaenids and 13 nymphalids) were recorded only from the reforested area. Two grassland species (Zizeeria karsandra and Junonia villida) were recorded only at Site G1. Species collected only at Site G2 were Catochrysops strabo, Euploea tuliolus, Acraea andromacha, Junonia hedonia, and Yoma sabina, three of which were forest species.

Neither species cited in IUCN Red List of 
A

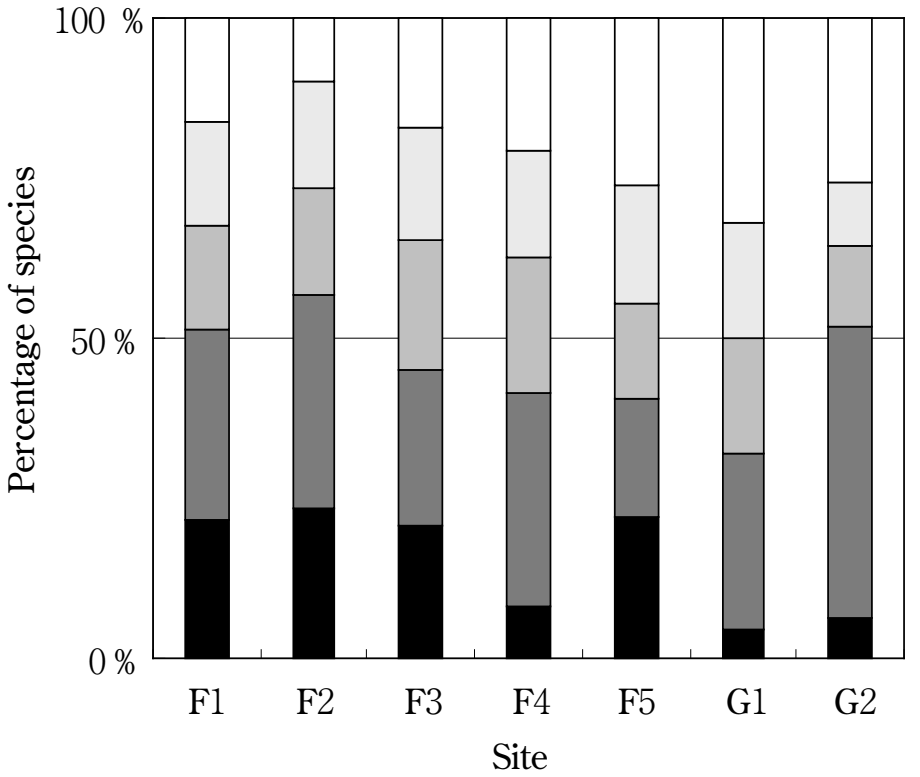

B

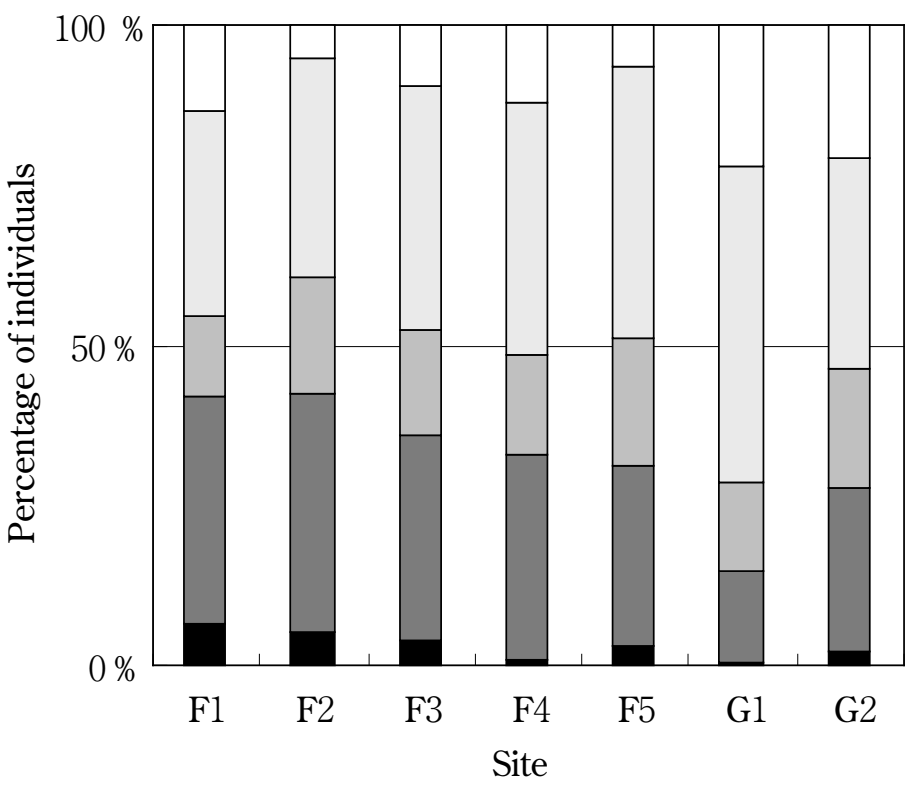

Grassland species

Savanna species

Multi-habitat species

Forest edge species

Forest species

Fig. 2. Composition of species (A) and individuals (B) at each study site based on the habitat preference.

Threatened Species nor Endangered Species was found. However, seven species sampled by us, Papilio demoleus, Appias olferna, Theclinesthes miskini, Mycalesis mineus, Tirumala ishmoides J. villida and A. andromacha, are newly recorded from Lombok. Only three species (Cepora temena, D. oraia and Ixias reinwardti) were endemic to Lesser Sunda and six were Sundaland-Wallacea species, whereas majority of the species recorded were widely distributed in Asian and/or Oceanian tropics or even ranging up to Africa (Fig. 3)

\section{Species richness in the reforestation area}

Sixty-three species were found from the reforestation area. Cumulative curve for recorded species asymptotically rises even at the end of sampling (Fig. 4), suggesting that we had sampled a large proportion of the 
Table 1. Habitat type, geographic range, larval food plant and occurrence of the species at each site in Sekaroh, Lombok.

\begin{tabular}{|c|c|c|c|c|c|c|c|c|c|c|}
\hline \multirow{2}{*}{ Species } & \multirow{2}{*}{$\begin{array}{l}\text { Habitat } \\
\text { type* }\end{array}$} & \multirow{2}{*}{$\begin{array}{l}\text { Geographic } \\
\text { range }^{* *}\end{array}$} & \multirow{2}{*}{ Larval food plant } & \multicolumn{7}{|c|}{ Site $^{* * *}$} \\
\hline & & & & $\mathrm{F} 1$ & $\mathrm{~F} 2$ & F3 & $\mathrm{F} 4$ & F5 & G1 & $\mathrm{G} 2$ \\
\hline \multicolumn{11}{|l|}{ Hesperidae } \\
\hline Hasora chromus & $\mathrm{F}$ & 5 & Pongamia (Leguminosae) & & + & & & & & \\
\hline Tagiades japetus & $\mathrm{F}$ & 5 & Dioscorea (Dioscoreaceae) & & & + & & + & & \\
\hline Parnara apostata & $\mathrm{G}$ & 2 & Gramineae (grass) & + & & & & & & + \\
\hline Pelopides agna & $\mathrm{G}$ & 5 & Gramineae (grass) & + & & & & + & & \\
\hline Borbo cinnara & $\mathrm{E}$ & 5 & Gramineae (grass) & & & + & & & & \\
\hline Potantus fettingi & $\mathrm{E}$ & 2 & Unknown (supposedly Gramineae) & + & + & + & & & & \\
\hline Taractrocera nigrolimbata & G & 2 & Unknown (supposedly Gramineae) & & + & + & + & + & + & + \\
\hline \multicolumn{11}{|l|}{ Papilionidae } \\
\hline Graphium agamemnon & $\mathrm{F}$ & 5 & Annonaceae & & + & & & + & & \\
\hline Graphium doson & $\mathrm{F}$ & 3 & Annonaceae, Magnoliaceae & & $(+)$ & & & & & \\
\hline Graphium eurypilus & $\mathrm{F}$ & 5 & Annonaceae, Magnoliaceae & & $(+)$ & & & & & \\
\hline Papilio canopus & $\mathrm{F}$ & 5 & Rutaceae & + & & & & & & \\
\hline Papilio demoleus & $\mathrm{S}$ & 5 & Citrus (Rutaceae) & + & & & & $(+)$ & & \\
\hline Papilio polytes & $\mathrm{F}$ & 3 & Rutaceae & & & + & & & & \\
\hline \multicolumn{11}{|l|}{ Pieridae } \\
\hline Appias albina & $\mathrm{E}$ & 5 & Capparis (Capparidaceae) & + & + & & + & & + & + \\
\hline Appias lyncida & $\mathrm{E}$ & 3 & Capparis, Crataeva (Capparidaceae) & + & + & + & + & + & + & + \\
\hline Appias olferna & $\mathrm{S}$ & 3 & Capparis (Capparidaceae) & + & + & & & + & & \\
\hline Belenois java & $\mathrm{S}$ & 4 & Capparis (Capparidaceae) & + & + & + & + & + & + & + \\
\hline Catopsilia pomona & $\mathrm{E}$ & 5 & Cassia (Leguminosae) & + & + & + & + & + & + & + \\
\hline Catopsilia pyranthe & $\mathrm{G}$ & 5 & Cassia, Sesbania (Leguninosae) & + & & & & & & + \\
\hline Cepora perimale & $\mathrm{S}$ & 4 & Capparis (Capparidaceae) & + & + & + & + & + & + & + \\
\hline Cepora temena & $\mathrm{E}$ & 1 & Unknown (supposedly Capparidaceae) & + & + & + & + & + & & + \\
\hline Delias oraia & $\mathrm{F}$ & 1 & Scurrula (Loranthaceae) & + & & + & + & & & + \\
\hline Eurema alitha & $\mathrm{M}$ & 5 & Leguminosae & + & + & + & + & + & + & + \\
\hline Eurema blanda & $\mathrm{E}$ & 5 & Leguminosae & + & + & & & & + & + \\
\hline Eurema hecabe & M & 6 & Leguminosae & + & $(+)$ & + & & + & & \\
\hline Hebomoia glaucippe & $\mathrm{E}$ & 3 & Capparis, Crataeva (Capparidaceae) & + & & & + & + & + & + \\
\hline Ixias reinwardti & $\mathrm{S}$ & 1 & Unknown (supposedly Capparidaceae) & + & + & + & + & + & + & + \\
\hline Leptosia nina & $\mathrm{M}$ & 3 & Capparis (Capparidaceae) & + & + & + & + & + & + & + \\
\hline \multicolumn{11}{|l|}{ Lycaeinidae } \\
\hline Castalius rosimon & $\mathrm{S}$ & 3 & Zizyphus (Rhamnaceae) & + & + & + & + & + & + & + \\
\hline Catochrysops strabo & $\mathrm{E}$ & 3 & Leguminosae & & & & & & & + \\
\hline Euchrysops cnejus & $\mathrm{G}$ & 5 & Leguminosae & & & & + & & & \\
\hline Everes lacturnus & G & 5 & Desmodium, Trifolium (Leguminosae) & & & & & + & & + \\
\hline Lampides boeticus & $\mathrm{O}$ & 6 & Leguminosae & & & & & + & & \\
\hline Nacaduva kurava & $\mathrm{F}$ & 5 & Myrsinaceae, Myricaceae, Sapindaceae & & & & & + & & \\
\hline Prosotas nora & $\mathrm{E}$ & 5 & $\begin{array}{l}\text { Combretaceae, Leguminosae, Myrtaceae, } \\
\text { Sapindaceae }\end{array}$ & & + & & & & & + \\
\hline Rapala manea & $\mathrm{E}$ & 3 & $\begin{array}{l}\text { Caprifoliaceae, Leguminosae, Rosaceae, } \\
\text { Sapindaceae, Verbenaceae }\end{array}$ & + & & & & & & + \\
\hline Theclinesthes miskini & G & 4 & Leguminosae, Myrtaceae, Sapindaceae & + & & & & & & + \\
\hline Zizeeria karsandra & G & 6 & $\begin{array}{l}\text { Amaranthaceae, Chenopodiaceae, Leguminosae, } \\
\text { Molluginaceae, Zygophyllaceae }\end{array}$ & & & & & & + & \\
\hline Zizina otis & $\mathrm{G}$ & 3 & Leguminosae & + & & + & + & + & + & + \\
\hline Zizula hylax & M & 6 & $\begin{array}{l}\text { Acanthaceae, Leguminosae, Scrophulariaceae, } \\
\text { Verbenaceae }\end{array}$ & + & + & + & & & + & \\
\hline \multicolumn{11}{|l|}{ Nymphalidae } \\
\hline Anosia chrysippus & G & 6 & Asclepiadaceae & + & + & + & + & + & + & + \\
\hline Anosia genutia & $\mathrm{M}$ & 3 & Asclepiadaceae & & & & + & & & \\
\hline Euploea eleusina & $\mathrm{F}$ & 3 & Streblus (Moraceae) & + & & & & & & \\
\hline Euploea leucostictes & $\mathrm{F}$ & 5 & Ficus (Moraceae) & + & & & & & & \\
\hline Euploea modesta & $\mathrm{F}$ & 5 & Apocynaceae, Moraceae & + & + & + & + & + & & + \\
\hline Euploea sylvester & $\mathrm{F}$ & 5 & Ficus (Moraceae) & + & + & + & + & + & & \\
\hline Euploea tuliolus & $\mathrm{F}$ & 5 & Apocynaceae, Moraceae & & & & & & & + \\
\hline
\end{tabular}




\begin{tabular}{|c|c|c|c|c|c|c|c|c|c|c|}
\hline Euploea climena & $\mathrm{F}$ & 2 & $\begin{array}{l}\text { Unknown (supposedly Moraceae or } \\
\text { Apocynaceae) }\end{array}$ & & & + & & & & \\
\hline Ideopsis juventa & $\mathrm{F}$ & 5 & Asclepiadaceae, Parsonisla (Apocynaceae) & & + & & + & & & \\
\hline Tirumala hamata & $\mathrm{F}$ & 4 & Asclepiadaceae & + & + & + & + & + & + & \\
\hline Tirumala ishmoides & $\mathrm{F}$ & 2 & Unknown (Ascrepiadaceae ?) & $(+)$ & & & & & & \\
\hline Tirumala limniace & $\mathrm{F}$ & 3 & Asclepiadaceae & + & + & & & + & & \\
\hline Acraea andromacha & $\mathrm{G}$ & 4 & $\begin{array}{l}\text { Passiflora (Passifloraceae), Hybanthus } \\
\text { (Violaceae) }\end{array}$ & & & & & & & + \\
\hline Ariadne ariadne & $\mathrm{S}$ & 3 & Ricinus, Tragia (Euphorbiaceae ) & + & + & + & + & + & + & \\
\hline Cethosia penthesilea & $\mathrm{E}$ & 2 & Adenia (Passifloraceae) & + & & & $(+)$ & & & + \\
\hline Phalanta phalantha & $\mathrm{E}$ & 6 & Flacourtiaceae, Salicaceae & & + & & & & & \\
\hline Cupha erymanthis & $\mathrm{E}$ & 3 & Flacourtiaceae & & + & & & & & \\
\hline Vindura dejone & $\mathrm{E}$ & 3 & Adenia (Passifloraceae) & & & & + & & & + \\
\hline Hypolimnas bolina & M & 5 & $\begin{array}{l}\text { Acanthaceae, Amaranthaceae, Convolvulaceae, } \\
\text { Malvaceae, Moraceae, Portulaceae, Urticaceae }\end{array}$ & + & + & + & + & + & & + \\
\hline Junonia erigone & $\mathrm{G}$ & 6 & Unknown (supposedly Acanthacae) & & + & + & + & + & & + \\
\hline Junonia hedonia & $\mathrm{E}$ & 4 & Acanthaceae & & & & & & & + \\
\hline Junonia orithya & $\mathrm{G}$ & 6 & Acanthaceae, Scrophulariaceae & + & & + & & & + & \\
\hline Junonia villida & G & 4 & $\begin{array}{l}\text { Acanthaceae, Plantaginaceae, Verbenaceae, } \\
\text { Scrophulariaceae, Genitianaceae }\end{array}$ & & & & & & + & \\
\hline Yoma sabina & $\mathrm{F}$ & 5 & Acanthaceae & & & & & & & + \\
\hline Neptis hylas & $\mathrm{E}$ & 3 & Leguminosae, Ulmaceae & + & + & + & + & + & + & \\
\hline Polyura alphinus & $\mathrm{F}$ & 3 & Unknown (supposedly Leguminosae) & & $(+)$ & & & $(+)$ & & \\
\hline Lethe europa & $\mathrm{F}$ & 3 & Gramineae (bamboo) & & & $(+)$ & & $(+)$ & & \\
\hline Melanitis leda & M & 6 & Gramineae (grass) & + & + & + & + & & + & \\
\hline Mycalesis mineus & $\mathrm{F}$ & 3 & Gramineae (grass) & + & + & + & $(+)$ & & & \\
\hline Mycalesis perseus & $\mathrm{E}$ & 5 & Gramineae (grass) & & & & & + & & + \\
\hline
\end{tabular}

*: F, forest species; E, forest edge species; S, savanna species; G, grassland species; M, multi-habitat species.

**: 1, Endemic to Lesser Sunda Islands; 2, Sundaland and Wallacea; 3, Asian tropics including Wallacea: 4, Oceanian tropics including Wallacea; 5, Asian and Oceanian tropics ; 6. Asian, Oceanian and African tropics.

***: +, present in the sample of June 2004 or later; (+), present in the sample of August 2003 and/or January 2004.

Table 2. Numbers of species belonging to Papilionidae, Pieridae and Nymphalidae known from Lombok and of those recorded from the reforestation area in this study.

\begin{tabular}{lcccc}
\hline & Papilionidae & Pieridae & Nymphalidae & Total \\
\hline Known from Lombok & 14 & 28 & 92 & 134 \\
Recorded in this study & 6 & 15 & 30 & 51 \\
\hline
\end{tabular}

species inhabiting the reforestation area, but there were still species not encountered by us in the area, or there were some newly settling species, or both. Assuming the number of species being stable throughout the study period in the reforestation area it is estimated at 81.0 by Jackknife 1, and 90.6 by Jackknife 2 .

The number of known species from Lombok and the number of species collected in this study are listed in Table 2. In total 134 species in these three families are known to occur in Lombok, including 127 so far known and six newly found in this study and one from our unpublished data. The 51 species of these families found in this study make up $38.1 \%$ of the total species known from Lombok.

\section{Comparison among the sampling sites}

Number of species, number of individuals, species diversity at each sampling occasion varied considerably, but in general these indices increased in rainy season and decreased in dry season (Figs. 5-7), apparently due to lack of fresh growth of food plants for the butterflies. These values tended to be higher in the reforestation area, but this was not always the case. Cumulative number of species recorded from Sites F1-5 steadily exceeded that from Site G1 (samples from June 2004 to January 2006; Fig. 8). It is also noteworthy that 


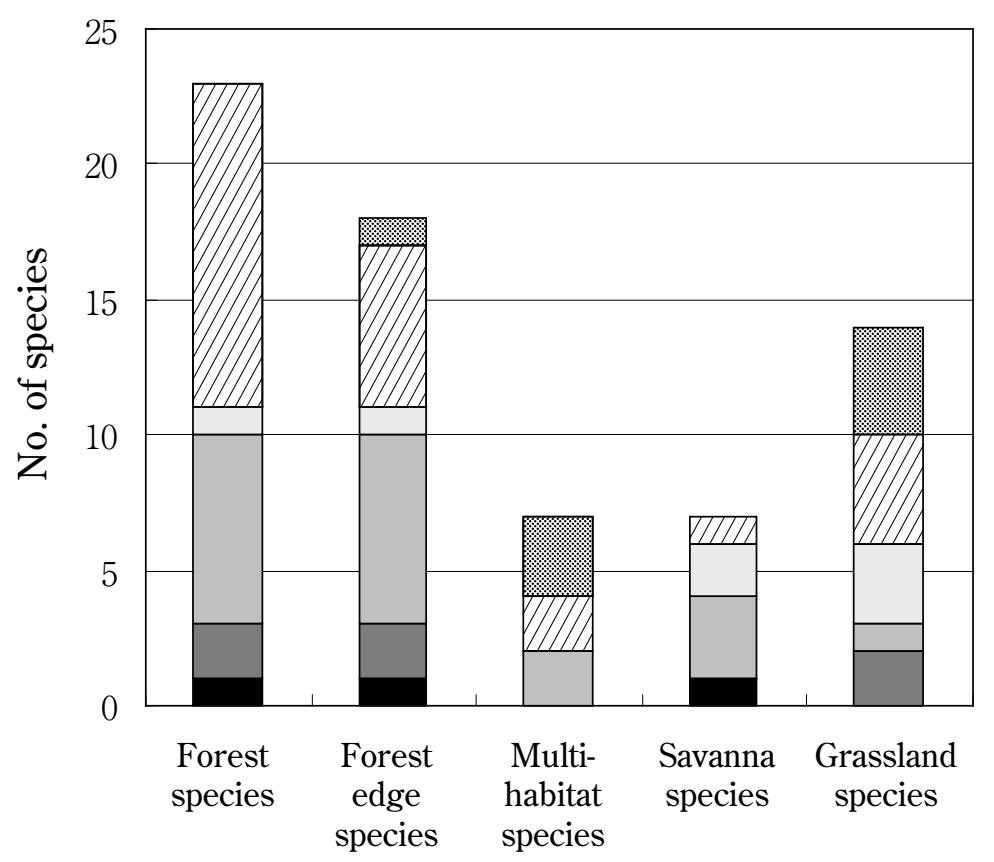

Asian, Oceanian \& African tropics

$\square$ Asian \& Oceanina tropics

Oceanian tropics

Asian tropics

Sundaland \& Wallacea

- Leeser Sunda

Fig. 3. Relationship between habitat preference and the geographical range for recorded butterfly species.

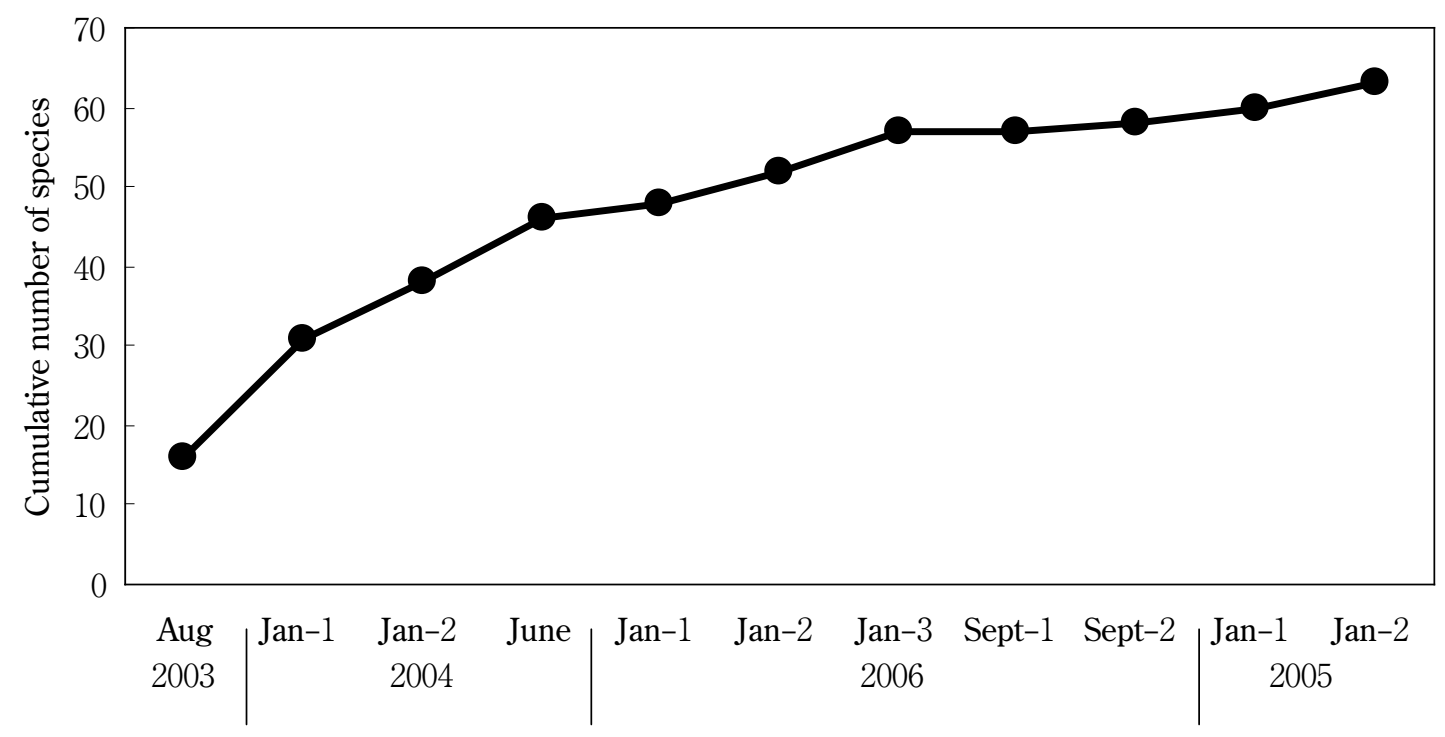

Fig. 4. Cumulative number of species recorded in the reforestation area (Sites A-E inclusive) during August 2003 to January 2006. 


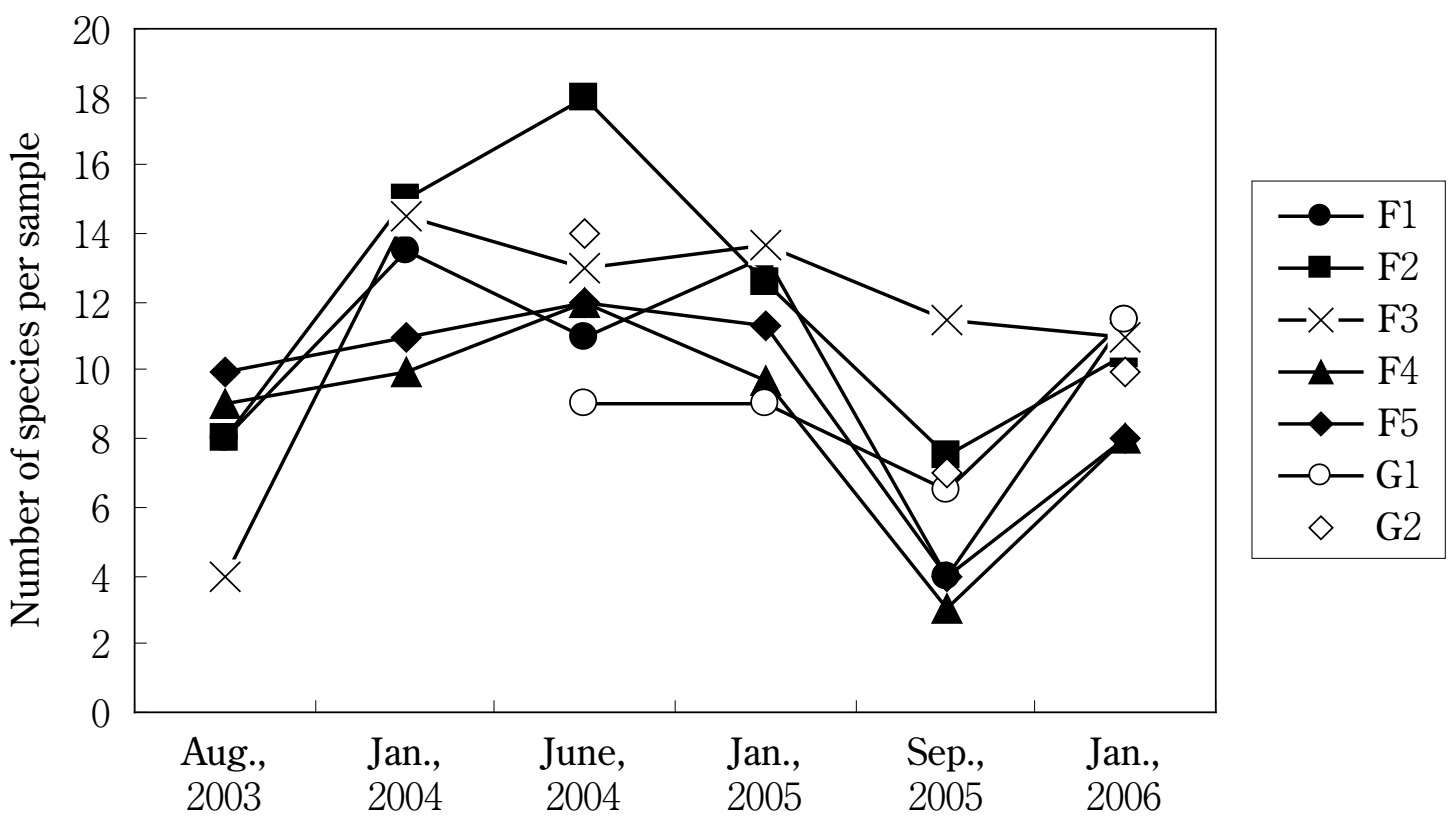

Fig. 5. Change in number of species collected at each sampling site.

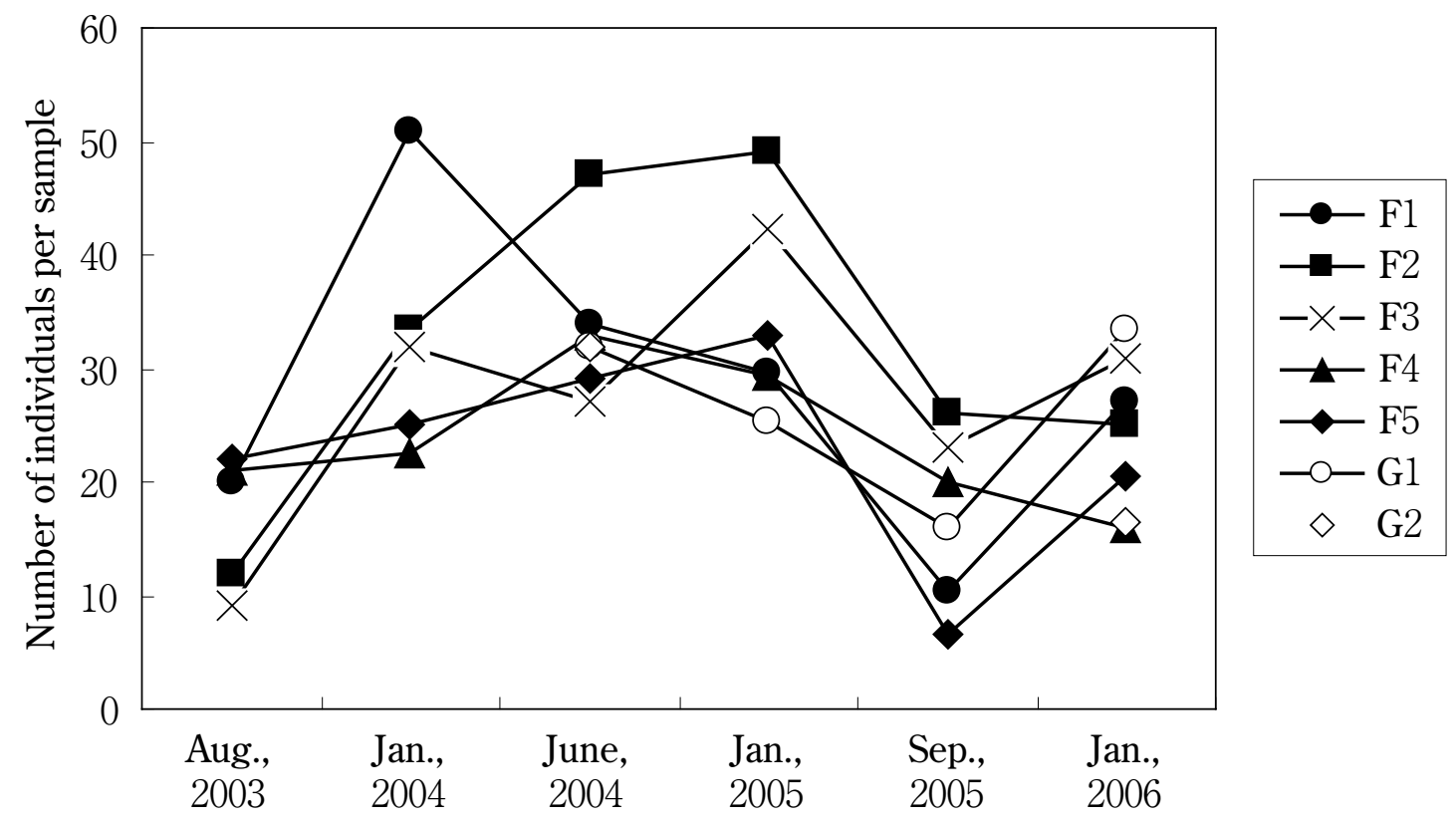

Fig. 6. Change in number of individuals collected at each sampling site. 


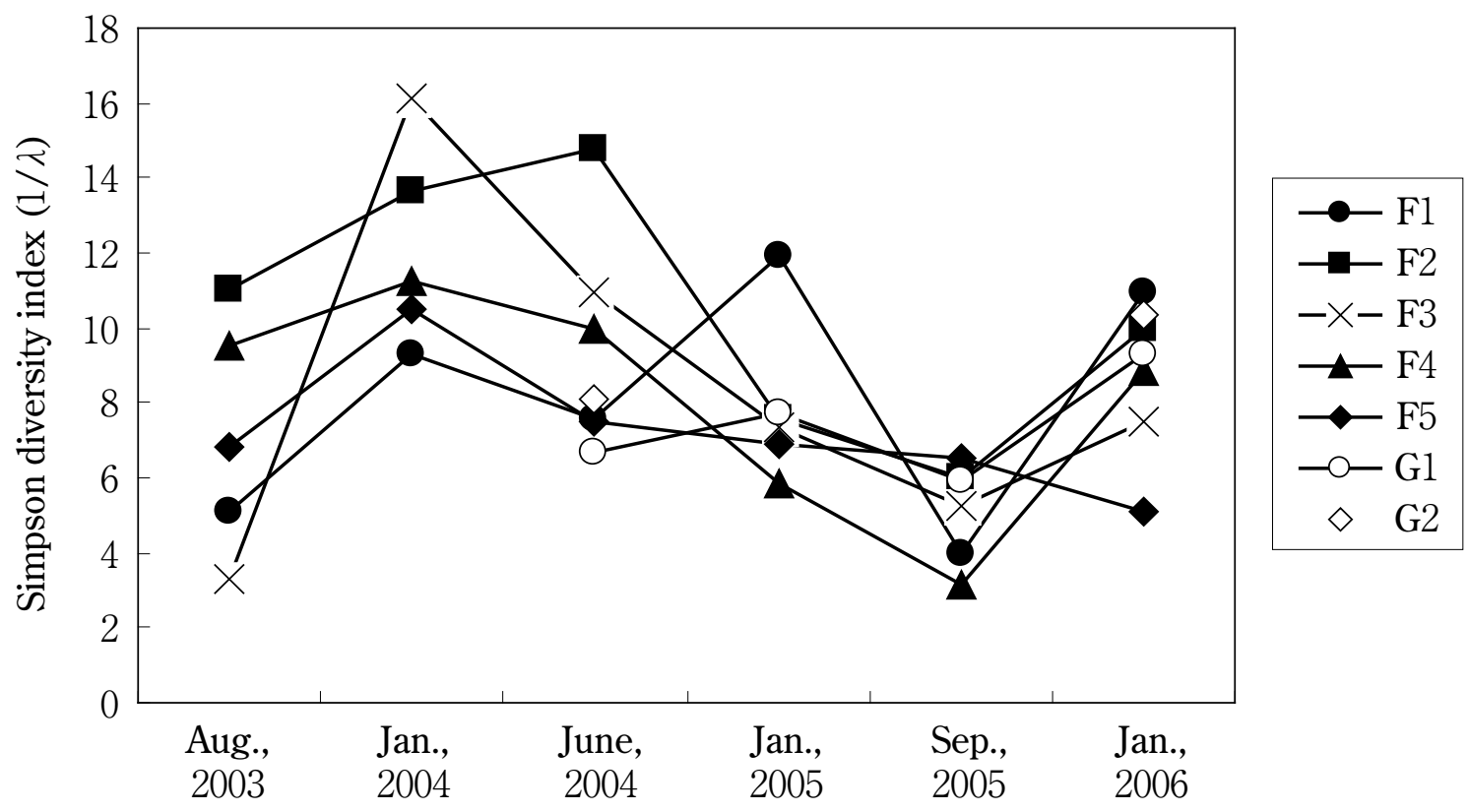

Fig. 7. Change in Simpson index of species diversity at each sampling site.

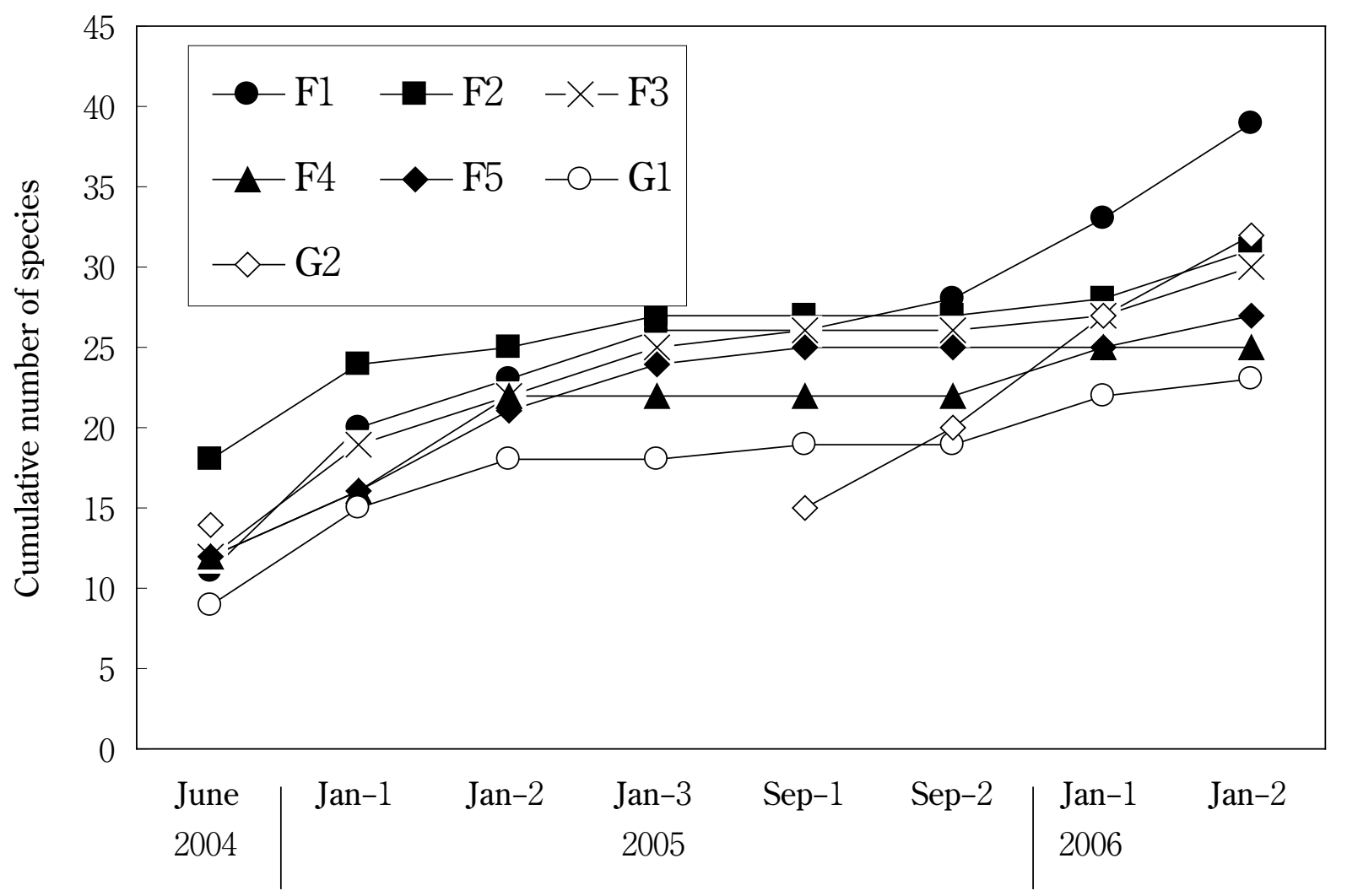

Fig. 8. Cumulative number of species recorded at each sampling site during June 2004 to January 2006. 


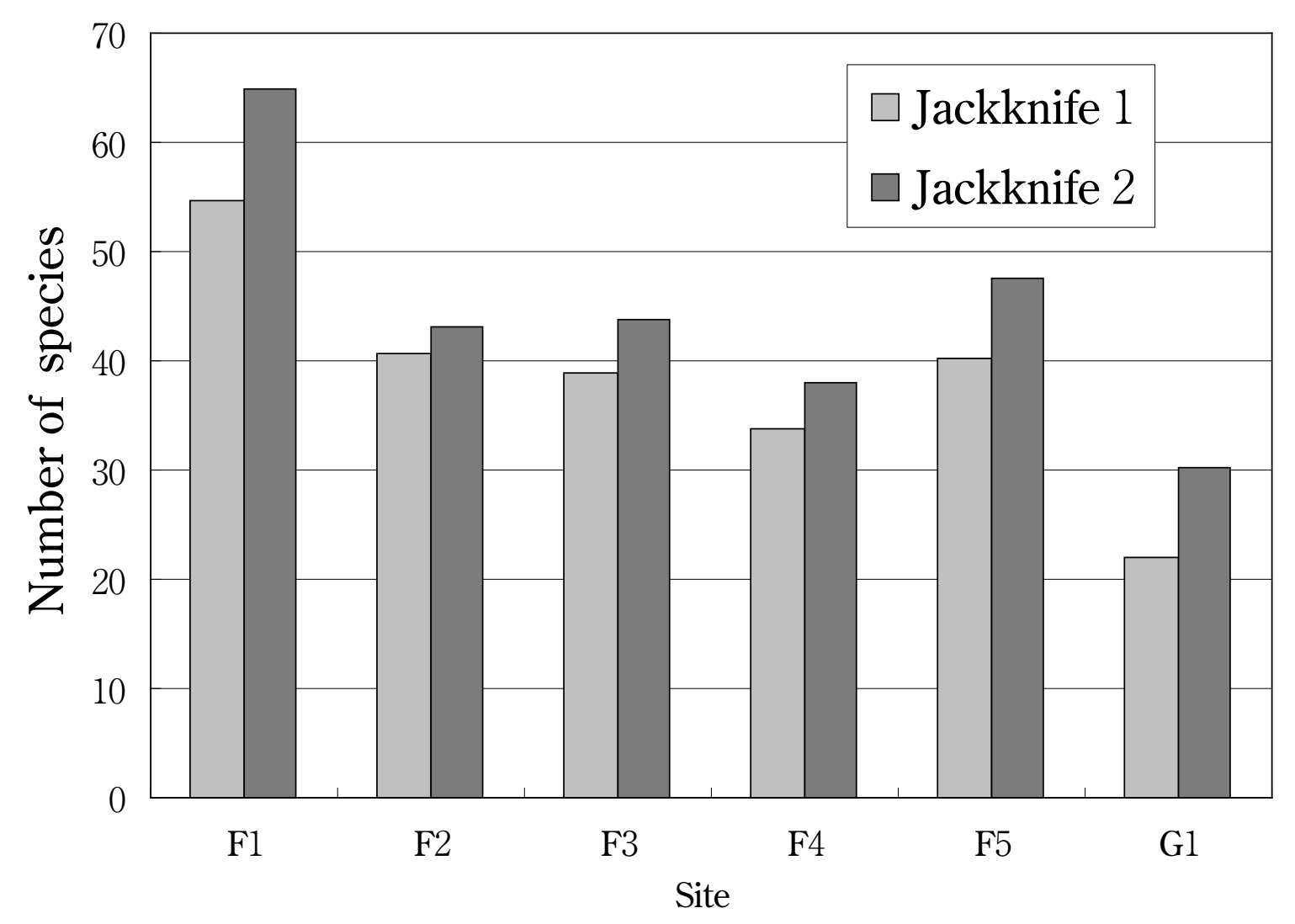

Fig. 9. Numbers of species at each site estimated by Jackknife 1 and Jackknife 2.

the cumulative number of species for Sites F1 and G2 remarkably increased in January 2006, and the species richness at Site G2 was rather high (Fig. 8). Total numbers of species estimated by the Jackknife 1 and 2 for Sites F1-5 also exceeded those for Site G1 (Fig. 9).

\section{DISCUSSION}

Papilio demoleus and A. olferna were originally dry savanna species. $P$. demoleus is distributed in the tropical and subtropical continental Asia and also occurs in Australia, and eastern part of New Guinea, but the specimens collected in the study area had characteristics of the Malayan subspecies malayanus. They are recently expanding their range, invading islands of Indonesia, Malaysia and the Philippines. This is probably caused by destruction of the rain forests on these islands as suggested by Matsumoto (2002).

Tsukada (1985) suggests that J. villida infrequently found on the Lesser Sunda Islands is a stray from Australia. In our study, this species appeared in four samples from Site G1 in January 2005 and January 2006, and we collected 12 individuals in total. Its repeated occurrences and rather high abundance suggest that this species has an established population in the study area of Sekaroh. J. villida is a species of arid environments, and it seems natural that it has been recorded only from the grassland (Site G1) in the study area.

Occurrence in a small area of over one-third of the total species of families Papilionidae, Pieridae and Nymphalidae known from Lombok means the Friendship Forest provides a good habitat for the butterflies. However, there are fewer forest species than light demanding species preferring open habitats (grassland, savanna and forest edge species). This is reflected in the predominance of Pieridae (mostly grassland, savanna and forest edge species), lack of Lybithinae of Nymphalidae (all forest species) and scarcity of Papilionidae (mostly forest species). The forest species recorded in this study are those commonly found in and around villages (e.g., Graphium agamemnon and Lethe europa) or in the forestry plantations (e.g., D. oraia and Eurema blanda), and there was no forest species typically found in mature natural forest.

The reason why grassland species and savanna species were also found in the plantation is that the elapsed time after the planting is short and that the 
canopy has not yet been closed. A lot of open space, therefore, still remained in the reforested area which is suitable for grassland and savanna species. However, some grassland species that emerged from grassland surrounding the reforested area may have migrated to the plantation forest. For instance, a number of Anosia chrysippus, a grassland species, were found in the plantation. But their eggs and larvae were found only on a milkweed, Calotropis gigantea, a larval host plant, which did not grow there. Similarly, a lot of forest species and forest edge species recorded outside the plantation forest might have been the individuals wandering out from the reforested area where they emerged. Due to the reforestation some forest species newly established in the reforested area, which may result in that a relatively large number of forest species were caught in the reforested area.

The reforestation may enable the following species to inhabit the reforested area, since reforestation often provides them with their host plants. Eurema spp. are defoliators of planted Enterolobium cyclocarpum, so that they are favored by the plantation. Catopsilia pomona is a defoliator of Cassia siamea, and was very abundant in reforested area every rainy season supposedly supported by flush of new leaves. Host plant of Polyura alphinus is unknown, but the very closely related Polyura athamas is known to feed on Darbergia (Leguminosae). Actually, our two specimens of $P$. alphinus were found on planted Darbergia latifolia, a possible host plant. D. oraia feeds on a mistletoe, Scurrula parasitica (Loranthaceae; parasites of trees). Establishment of the plantation should have been a prerequisite for this parasitic host plant, hence for the butterfly to establish its population. Because the mistletoes do only parasitize the well-grown trees, the fact that $D$. oraia was sampled in 2006 may suggest that the trees in the reforested area grew well.

Some forest species collected in a small number of individuals in the reforested area may have flew into there from the adjacent littoral forest. One example is Hasora chromus which is an oligophagous species feeding on Pongamia; the latter was not found in the reforested area but a congeneric species, Pongamia velutina, was found in the adjacent littoral forest (Kiyono and Rachman, 2004, 2005). Tagiades japetus may also have emerged from the adjacent littoral forest, because the Dioscoreaceae, the host plant of T. japetus, was not found in the reforested area.

Forest species such as Euploea spp., Ideopsis juventha, Tirumala spp. belonging to the subfamily Danainae do not depend on afforestaion tree species, but were collected in comparatively large numbers in the reforested area, suggesting that their host plant grows naturally there. In fact Apocynaceae (Tabenaemontana pandacaqui and Wrightia pubescens) and Moraceae (Fatoua pilosa and Ficus religiosa) which are host plants of Euploea, and also Asclepiadaceae (Calotropis gigantean and Marsdenia tenacissima) which are host plants of Ideopsis and Tirumala were found in the reforested area (Kiyono and Rachman, 2004, 2005). At Site F4 the total number of species and also the number of forest species were few, reflecting that the under-growth was poor and the forest cover was simple because L. leucocephala was mainly replanted after the forest fire.

From our results on the butterfly fauna of Lombok, Indonesia, forest plantation on the deforested grassland did improve the biodiversity, meaning that the plantation does not have an adverse effect on the biodiversity of deforested area. Chey et al. (1997) assessed the diversity of macromoths in various plantations and natural secondary forests in Sabah, Borneo, Malaysia, and concluded that the moth diversity in the deforested grassland is the lowest among the assessed sites and also the diversity in the forest plantations of Acacia mangium, Gmelina arborea, Paraserianthes falcataria, Pinus caribaea was unexpectedly high. Although such results that forest plantation improved the biodiversity in degraded forests are limited, our results and Chey et al. (1997) support that forest plantation onto the degraded forest does not adversely affect the biodiversity.

If any negative impact is considered significant in the CDM-A/R project by the project participants or the host party, we have to describe the results of an environmental impact assessment in the project design document (PDD), which insist on the expenses of environmental assessment. Since the entity undertaking a small scale CDM-A/R is assumed to be NGO, NPO, a group of local people and so on, it is not a practical scenario for such entities to conduct an environmental assessment when the negative impact would be significant. It is more practical for those not to select the sites where such a negative impact would clearly be possible. From the standpoint of biodiversity, therefore, the following places are not recommended as a site of a small scale CDM-A/R.

1) where the present vegetation is primary one.

2) where species in the IUCN Red List of Threatened Species live.

3) where endangered or rare species listed by the host country live.

From the viewpoint of environmental impact, tree species to be planted in a small scale CDM-A/R should 
be carefully chosen with two points in mind. Firstly, unexpected escape of planted trees and their subsequent invasion into the local ecosystem should be avoided, and secondly, outbreaks of pest insects should also be avoided. In practice, tree species that should not be chosen are,

1) Exotic species which have never been introduced to a host country.

2) Species which are likely to disperse or naturalize there, such as Cinchona pubescens and $L$. leucocephala, listed in "100 of world's worst invasive alien species" (www.issg.org/database).

3) Species which have serious insect pests that prevent the growing of plantation forest, such as with Meliacenae trees with Mahogany shoot borer (Hypsipyla spp.), teak with teak beehole borer (Xyleutes ceramica), etc. (Hutacharern, 1983; Newton et al., 1993; Mayhew \& Newton, 1998; Matsumoto \& Kotulai, 2000; Gotoh et al, 2003, 2007).

To facilitate CDM-A/R we need to accumulate more studies comparing the diversity between a plantation forest and a degraded forest or grassland, which can be a candidate place for CDM-A/R.

ACKNOWLEDGEMENTS We thank Japan International Forestry Promotion and Cooperation Center (JIFPRO) and West Nusa Tengara Provincial Forestry Service (DKNTB) for allowing us to survey butterflies in the Japan-Indonesia Friendship Forest, Sekaroh, Lombok. Thanks are also offered to Dr. Yoshiyuki Kiyono of FFPRI for his comment on the manuscript, and Mr. Kiyoshi Maruyama and Mr. Yûsuke Takanami for identification of some specimens of Hesperiidae and Lycaenidae, respectively. This study was conducted as a part of a project funded by the Forestry Agency of Japan, "Forestation: basic data collection aiming at small scale afforestation/reforestation CDM in environmental planting".

\section{REFERENCES}

Ackery, P.R. \& Vane-Wright, R.I. 1984. Milkweed butterflies. British Museum (Natural History), London, 425 pp.

Ashton, P.S. 1971. The plants and vegetation of Bako National Park. Malayan Nature Journal, 24: 151-162.

Bascombe, M.J., Johnston, G. \& Bascombe, F.S. 1999. The butterflies of Hong Kong. Academic Press,
London. 422 pp. +222 pls.

Braby, M.F. 2000. The butterflies of Australia: their identification, biology and distribution. CSIRO Publishing, Collingwood, 976 pp.

Chey, V.K., Holloway, J.D. \& Speight, M.R. 1997. Diversity of moths in forest plantations and natural forest in Sabah. Bulletin of Entomological Research, 87: 371-385.

Clearry, D.F.R. \& Mooers, A.Ø. 2006. Burning and logging differentially affect endemic vs. widely distributed butterfly species in Borneo. Diversity and Distribution, 12: 409-416.

Corbet, A.S. \& Pendlebury, H.M. 1992. The butterflies of the Malay peninsula. 4th edn. (Revised by J.N. Eliot) . Malayan Nature Society, Kuala Lumpur, Lumpur, x +595 pp. +69 pls.

Crambrook, Earl of \& Edwards, D.S. 1994. A tropical rain forest: the nature of biodiversity in Borneo at Belalong, Brunei. The Royal Geographical Society \& Sun Tree Publication, Singapore, 389 pp.

Erwin, T.L. 1982. Tropical rain forests: their richness in Coleoptera and other arthropod species. The Coleopterists' Bulletin, 36: 74-75.

Erwin, T.L. \& Scott, J.C. 1980. Seasonal and size patterns, trophic structure and richness of Coleoptera in the tropical arboreal ecosystem: the fauna of the tree Luehea seemanii Triana and Planch in the Canal Zone of Panama. The Coleopterists' Bulletin, 34: 305-322.

FAO-UNESCO. 1979. Soil Map of the World Vol. Southeast Asia, UNESCO, Paris, 149 pp.

Fukuda, H., Hama, E., Kuzuya, T., Takahashi, A., Takahashi, M., Tanaka, B., Tanaka, H., Wakabayashi, M. \& Watanabe, Y. 1982. The lifehistories of butterflies in Japan. Vol. 1. Hoikusha Publishing, Osaka, 277 pp.

Fukuda, H., Hama, E., Kuzuya, T., Takahashi, A., Takahashi, M., Tanaka, B., Tanaka, H., Wakabayashi, M. \& Watanabe, Y. 1983. The lifehistories of butterflies in Japan. Vol. 2. Hoikusha Publishing, Osaka, 325 pp.

Fukuda, H., Hama, E., Kuzuya, T., Takahashi, A., Takahashi, M., Tanaka, B., Tanaka, H., Wakabayashi, M. \& Watanabe, Y. 1984a. The lifehistories of butterflies in Japan. Vol. 3. Hoikusha Publishing, Osaka, 373 pp.

Fukuda, H., Hama, E., Kuzuya, T., Takahashi, A., Takahashi, M., Tanaka, B., Tanaka, H., Wakabayashi, M. \& Watanabe, Y. 1984b. The lifehistories of butterflies in Japan. Vol. 4. Hoikusha 
Publishing, Osaka, 373 pp.

Gotoh, T. Kotulai, J. R.\& Matsumoto, K. 2003. Stem borers of teak and Yemane in Sabah, Malaysia, with analysis of attacks by the teak beehole borer (Xyleutes ceramica Wlk.). JARQ, 37: 253-261.

Gotoh, T. Eungwijarnpanya, S., Yincharoen, S., Choldumrongkul, S., Nakamuta, K., Pholwicha, P., Piananurak, P. \& Hutacharern, C. 2007. Emergence, oviposition and larval behaviors in the teak beehole borer (Xyleutes ceramica Wlk.) in Northern Thailand (Lepidoptera: Cossidae). JARQ, 41: 307-314.

Hill, J.K., Hamer, K.C., Lace, L.A. \& Banham, W.M.T. 1995. Effects of selective logging on tropical forest butterflies on Buru, Indonesia. Journal of Applied Ecology. 32: 754-760.

Hutacharern, C. \& Tubtim, N. 1995. Checklist of forest Insects in Thailand, Office of Environmental Policy and Planing, Bangkok, 392 pp.

Igarashi, S. \& Fukuda H. 1997. The life histories of Asian butterflies Vol. 1. Tokai University Press, Tokyo, 549 pp.

Igarashi, S. \& Fukuda H. 2000. The life histories of Asian butterflies Vol. 2. Tokai University Press, Tokyo, 711 pp.

de Jong, R. 2004. Phylogeny and biogeography of the genus Taractrocera Butler, 1870 (Lepidoptera: Hesperiidae), an example of Southeast AsianAustralian interchange. Zoologische Mededelingen, Leiden 78: 383-415.

de Jong, R. \& Treadaway C.G. 1993. The Hesperiidae (Lepidoptera) of Philippines. Zoologische Verhandelingen, Leiden 288: 1-125.

Kiyono, Y. \& Rachman I. 2004. An analysis of the influence on flora. Fiscal report of forestation basic data collection aiming at small scale environmental planting CDM project, 2003, Forestry and Forest Products Research Institute, Tsukuba, pp. 56-58 (In Japanese).

Kiyono, Y. \& Rachman, I. 2005. An analysis of the influence on flora. Fiscal report of forestation basic data collection aiming at small scale environmental planting CDM project, 2004, Forestry and Forest Products Research Institute, Tsukuba, pp. 51-57 (In Japanese).

Lammertink, M., Setiorini, U. \& Prawiradilaga, D. (eds.) 2004. As a phoenix from the flames? The recovery potential of biodiversity after logging, fire and agroforestry in Kalimantan and Sumatra. Netherland Science Foundation, Lembaga Ilmu
Pengetahuan Indonesia \& Pusat Informasi Lingkungan Indonesia, Jakarta, iv + 55 pp.

Lewis, O.T. 2001. Effect of experimental selective logging on tropical butterflies. Conservation Biology 15: 389-400.

Maruyama, K. \& Otsuka, K. 1991. Butterflies of Borneo. Vol. 2, No. 2. Hesperiidae. Tobishima Corp., Tokyo, 89 pp. in Japanese and 83 pp. in English +48 pls.

Matsumoto, K. 2002. Papilio demoleus (Papilionidae) in Borneo and Bali. Journal of the Lepidopterists' Society, 56: 108-111.

Matsumoto, K. \& Kotulai, J.R. 2000. Insect pests of mahoganies with particular attention to shoot borers. In: Chan H.H. \& Matsumoto, K. (eds.) Proceedings of the Seminar on High Value Timber Species for Plantation Establishment- Teak and mahoganies, 1-2 December 1998, Tawau, Sabah. Japan International Research Centre for Agricultural Sciences, Tsukuba, pp. 67-79.

Mayhew, J.E. \& Newton, A.C. 1998. The Siliviculture of Mahogany, CABI Publishing, Oxon, 226 pp.

Morisita, M. 1996. On the influence of the sample size upon the values of species diversity. Japanese Journal of Ecology, 46: 269-289. (in Japanese with English abstract)

Newton, A.C., Baker, P., Ramnarine, S., Mesén, J.F., \& Leakey, R.R.B. 1993.The mahogany shoot borer: prospects for control. Forest Ecology and Management, 57: 301-328.

Otsuka, K. 1996. Bornean butterflies examined through distribution. Research Bulletin of Fujimura Girls Junior and Senior High School, 12: 1-52.

Palmer, M.W. 1991. Estimating species richness: the second-order jackknife reconsidered. Ecology 72: 1512-1513.

Primack, R. and Corlett, R. 2005. Tropical rain forests: An ecological and biogiographical comparison. Blackwell Publishing, Malden, 319 pp.

Robinson, G.S. \& Tuck, K.R. 1993. Diversity and faunistics of small moths (Microlepidoptera) in Bornean rain forest. Ecological Entomology, 18: 385-393.

Seki, Y., Takanami, Y. \& Otsuka, K. 1991. Butterflies of Borneo. Vol. 2, No. 1. Lycaenidae. Tobishima Corp., Tokyo, 139 pp. in Japanese and 113 pp. in English + 72 pls.

Simpson, E. H. 1949. Measurement of diversity. Nature, 163: 668 ,

Slik, J.W.F., Verburg, R.W. \& Kesseler, P.J.A. 2002. Effects of fire and selective logging on the tree 
species composition of lowland dipterocarp forest in East Kalimantan, Indonesia. Biodiversity and Conservation, 11: 85-98.

Smith, E.P. \& Belle, G. van 1984. Nonparametric estimation of species richness. Biometrics, 40: 119-129.

Spitzer, K., Jaros, J., Havelka, J. \& Leps, J. 1997. Effect of small-scale disturbance on butterfly communities of an Indochinese montane rainforest. Biological Conservation, 80: 9-15.

Tennnent, J. 2002. Butterflies of the Solomon Islands. Systematics and biogeography. Storm Entomological Publications, Aylsham, 413 pp.

Tsukada, E. \& Nishiyama, Y. 1980. Butterflies of the South East Asian islands. Vol. 1. Papilionidae. Prapac, Tokyo, 459 pp.

Tsukada, E. 1985. Butterflies of the South East Asian islands. Vol. 4. Nymphalidae (1). Prapac, Tokyo, 558 pp.

Tsukada, E. 1991. Butterflies of the South East Asian islands. Vol. 5. Nymphalidae (2). Azumino Butterflies research Institute, Matsumoto, $576 \mathrm{pp}$.

United Nations 1998. Kyoto Protocol to the United Nations Framework Convention on Climate Change, $20 \mathrm{pp}$.

United Nations 2005. Simplified modalities and procedures for small-scale afforestation and reforestation project activities under the clean development mechanism in the first commitment period of the Kyoto Protocol and measures to facilitate their implementation. Decision-/CP.10, 15 pp. (http://unfccc.int/meetings/cop_10/ items/2944.php)

Vane-Wright, R.I. \& Jong R. de 2003. The butterflies of Sulawesi: annotated checklist for a critical island fauna. Zoologische Verhandelingen, Leiden, 343: $1-267$.

Whitmore, T. C. 1990. An introduction to tropical rain forests. Clarendon Press. $226 \mathrm{p}$.

Willot, S.L., Lim, D.C., Compton, S.G. \& Sutton, S.L. 2000. Effects of selective logging on the butterflies of a Bornean rain forest. Conservation Biology, 14: 1055-1065.

Worda, H. 1978. Seasonal fluctuations in rainfall, food and abundance of tropical insects. Journal of Animal Ecology, 47: 369-381.

Worda, H. 1983. Long-term stability of tropical insect populations. Researches on Population Ecology Supplement, 3: 112-126.

Yata, O. \& Morishita, K. 1981. Butterflies of the South
East Asian islands. Vol. 2. Pieridae-Danaidae. Prapac, Tokyo, 628 pp.

Received $12^{\text {th }}$ July 2007

Accepted $14^{\text {th }}$ Mar. 2008 